\title{
The Information and Communication Technology Infrastructure on University of Mines and Technology Campus and Its Impact on Library e-Resource Accessibility*
}

\author{
${ }^{1}$ P. Anafo, ${ }^{1}$ S. Akpah and ${ }^{1}$ Y. Ofori \\ ${ }^{1}$ University of Mine and Technology, Tarkwa
}

\begin{abstract}
Anafo, P. Akpah, S. and Ofori, Y. (2020), The Information and Communication Technology Infrastructure on University of Mines and Technology Campus and its Impact on Library E-Resource Accessibility", Ghana Mining Journal, Vol. 20, No. 1, pp. 75 - 83.
\end{abstract}

\begin{abstract}
The University of Mines and Technology (UMaT), Tarkwa, Ghana has a Local Area Network (LAN) infrastructure whose primary purpose is to facilitate research; teaching and learning; and information dissemination. The LAN infrastructure spans a maximum distance of 1.39 square-kilometers with an upload and download speed of $115 \mathrm{Mb} / \mathrm{s}$ and interconnects the administration block, faculties, library and halls of residence with high-speed ethernet links operating over a dedicated fiber optic backbone. The LAN infrastructure with connectivity to the internet impact operations in various sections of the University, notably, the University Library. The main purpose of the library is to interact with different information networks to make available e-resource materials to students, academic and non-academic staff. This can only be achieved over a dedicated LAN infrastructure. The introduction of Library Management Systems (Koha), Online Public Access Catalogue (OPAC) and the UMaT Space has improved library services such as document delivery, circulation and borrowing, amongst others. However, there exist a major challenge associated with library e-resources accessibility. This paper sought to investigate the factors hindering library e-resource accessibility for the purposes of improving research. Questionnaire was administered to respondents to solicit primary information while secondary information was obtained from published literature. 537 out of 855 participants responded to the questionnaire administered. $351(65.36 \%)$ represented undergraduate students, $73(13.60 \%)$ represented postgraduate students, $87(16.20 \%), 21(3.91 \%), 5(0.93 \%)$ represented teaching, non-teaching and library staff respectively. The responses were analysed using simple tables and pie charts. Results from the study showed inadequate access points to enable users access these e-resource materials and lack of knowledge about the existence of these resources. The investigation further revealed the need for the library to embark on an information literacy drive for both students and academic staff. Various ways of improving e-resource accessibility was suggested.
\end{abstract}

Keywords: Local Area Network, ICT Infrastructure, Online Public Access Catalogue (OPAC), E-Resources

\section{Introduction}

The efficiency of a library as an integral part of any higher education is determined by the ease of access to information resources by users of the library. Libraries in the $21^{\text {st }}$ century play crucial roles by serving as knowledge hubs to provide the right information to the right set of users at the right time and in the much-needed quantity. Advances in information technology have led to far-reaching developments in most higher learning institutions; a typical example is the application of digital information in teaching, learning and research. Most libraries in Ghana to which the University of Mines and Technology library is no exception are equipped with materials both in traditional and electronic formats; users are offered a wide variety of information resources. According to Capron (2000), users previously relied on traditional mediums of information provision such as telephone, television, books, newspapers and magazines to send and receive information. However, the advent of internet technologies and data communication systems have completely revolutionized and made access to information very easy. Before the emergence of ICT, library service provision was cumbersome, time wasting, without giving any room for flexibility. However, with the integration of ICT into library services, particularly at the higher educational institutions, access to eresource materials has been made easy as well as closed the global gap for information retrieval (Omagbemi, Akintola and Olayiwola, 2004). Information and Communication Technology (ICT) is the combination of computer and other telecommunication devices which is made up of three basic components namely, electronic processing using the computer; transmission of information using telecommunication devices and dissemination of information using multimedia equipment. The introduction and adoption of ICT has impacted positively by offering ample opportunities for libraries to automate their traditional processes, implement effective library resource sharing networks, develop institutional repositories, provide value-added information services and initiate capacity-building programs for their staff. It is clear that University libraries stand a chance of benefiting immensely from the application of ICT as it facilitates easy and instantaneous access to information. It provides 
opportunities for libraries to widen the scope of their resources/services and increase their significance within the institutions they serve. The continual availability of information in electronic form allows for many information needs to be satisfied with decreased or no involvement from library staff.

Even though extensive research into the application of information technologies in libraries has been carried out, this study focuses on the state and availability of ICT facilities deployed at the University of Mines and Technology (UMaT) and its application to the management of library services on the campus. Presently, it is observed that the application of ICT to library activities and services in UMaT is woefully inadequate, this is primarily due to the state of ICT infrastructural distribution on campus and the library, inadequate access points to facilitate user access and lack of technical knowhow on the part of library staff to make use of these technologies. Most library staff give preference to the manual ways of doing things irrespective of the enormous benefits to be derived from the application of ICT. Those who are aware of the numerous benefits are petrified of being sidelined from their jobs. It is against this background that there is the need to understand the possible areas where the application of ICT is essential for the overall improvement of UMaT library services. This will be possible by improving the library network topology, network access points, electronic databases, e-journals and electronic resources deployed. The main objectives of the study is to understand the present state of automation processes been carried out in the UMaT library and how it impacts on e-resource accessibility.

\subsection{Literature Review}

A great deal of research has been undertaken on different aspects of electronic resources and applications deployed in libraries across many institutions. However, very little information is captured on the use of electronic resources, its management and associated problems in libraries. Presently, many libraries have adopted the use of Electronic Information Resources (EIR) as a way of rendering library services to their communities. This is supported by efficient ICT infrastructures, online databases, search engines and the World Wide Web (WWW). O'Brien (2002), shares that, ICT have become a pivotal component for successful businesses and organisations as it enhances their business processes and gives them competitive edge. Most organisations rely heavily on ICT to enhance the way they work, relate and respond to their customer needs. The enormous benefits to be derived from ICT does not exempt book libraries whose primary purpose is to serve as knowledge hubs to those who access them. Views shared by to Ddembe \& Baryamureba (2006), indicate that, present day library users want to have access to books and other resources in a timely manner and in the right quantity thus they visit libraries where the needed information or resources are widely available and easy retrieval tools come in handy. Utor (1999), reiterates the facts to indicate that information has become a major economic resource for individuals, corporations, and institutions and the daily growth of it brings about problems of location, acquisition, organisation, and funds. These problems are further exacerbated when users find it difficult to locate and use the information, they consider useful. Other views shared by Dafiaghor (2012) explained that the integration of information technology in academic libraries have extremely affected all aspects of information generation, processing, storage, and transfer. Its magnificent development has dramatically changed the mode of library operations and information services. Hundreds of thousands of monographic materials, journals, learning resources, databases, etc. are now available in electronic formats, and these materials can now be accessed anywhere, thereby enhancing information service delivery. The speed in information processing capabilities and connectivity of computers, networking equipment's and internet technologies significantly increases the efficiency of business processes as well as enhance communication among end users. One of the standards by the International Certified Evaluation and Accreditations (2009-2010), indicate that research should always be conducted in a manner that forms a foundation for achieving high education goals. For high research works to take place, Universities must endeavor to provide quality library and information services which include current literature, in a conducive environment and accessible everywhere. The library must be stocked and well managed with resources like e-books, academic journals, audio visual and other research materials which must be collected, classified and organized systematically. The massive deployment of internet technologies in most organisations today have had profound effects on the promotion of information generation and sharing; especially in academic institutions, thus enhancing rapid transactions and supporting online collaboration among individuals, institutions and organisations. According to Ogunsola (2004), these technologies when effectively deployed have the potential to develop "virtual campuses" and "virtual libraries" thus, increasing students' access and participation. Other views shared by Daniel (2000), state that Nancy Schiller defined virtual libraries as the use of computers, telecommunication and internet technologies to 
make information resources easily accessible. Currently, the concept is mostly referred to as electronic library, automated library, or simply library without boundaries (Ogunsola, 2004). In the $21 \mathrm{st}$ century, ICT and the internet has revolutionised information access and library information service delivery around the world. Its effect on academic institutions cannot be quantified making user access to library resources ubiquitous. To meet the ever-increasing demand for information availability and improved research works, academic libraries now subscribe to electronic resource portals to access e-books, journals and on-line bibliographic databases. According to Idowu (2009), the availability of electronic resources enables remote access to much needed information at the right place and at the right time. Meanwhile, despite the numerous benefits offered by integrating ICT and internet technologies to aid library information service delivery, studies have identified a number of associated problems. These problems include inadequate resources, mainly computers, poor internet connectivity and lack of appropriate technical skills among library staff and users. Views shared by Ray and Day (1998), state that the factors affecting students' access and use of eresource materials are due to the lack of effective information retrieval skills, this is further exacerbated by the lack of technical support staff and training.

\section{Resources and Methods Used}

The study adopted both the quantitative and qualitative survey techniques. Both primary and secondary sources of information were used to achieve the goals of this paper. The primary sources consisted of responses to questionnaires administered to students (undergraduates and postgraduates), staff (academic and non-academic) and library staff of the University of Mines and Technology, Tarkwa. The secondary sources consisted of published literature, journal articles, internally generated documents like publications of UMaT Recorders, Statutes of the University, The Vice Chancellors's Reports, internet sources and interaction with the head of the ICT unit of the University thus to have a first-hand understanding of the ICT infrastructure on campus. Responses to the questionnaire were collated during the period February 2018 to May 2018. The questionnaire consisted of questions on general institutional information, hardware and software specification, library automation, accessibility of digital library, internet connectivity, library website, technically knowledgeable ICT staff and barriers to the usage of ICT technologies, all based on the objectives of the study.
The study was limited to the impact of the ICT infrastructure on library e-resource accessibility at the University of Mines and Technology library. UMaT is located at Tarkwa, 89 kilometers from Takoradi, the Western Regional capital of Ghana. The University has three (3) faculties, namely, Faculty of Mineral Resources Technology (FMRT) made up of six (6) academic departments, Faculty of Engineering (FOE) made up of five (5) academic departments and Faculty of Integrated Management Studies (FIMS) made up of two (2) academic departments. There is a School of Postgraduate Studies which coordinates all postgraduate study programmes. The total number of students (i.e. undergraduate and postgraduate) is 2,692 and a dedicated staff strength of 464 employees made up of teaching and non-teaching staff. Over the years, the University has seen an average annual growth rate of approximately $14 \%$ in its student population, thus the need for continual investment in modern technologies to support effective teaching and learning. To this effect, UMaT has invested in the provision of a robust ICT infrastructure to strengthen the research arm of the University, and to meet the daily bandwidth demands of the University community. This is further exacerbated by the annual subscription to online e-resources, journals and other research banks by the University Library.

\subsection{UMaT ICT Infrastructure}

The ICT infrastructure on UMaT campus spans a maximum distance of approximately $1.39 \mathrm{~km}$. The main LAN backbone located at the Network Operation Centre (NOC) also doubles as the main base station. A point to point internet connection with download and upload bandwidth stream of $115 \mathrm{Mb} / \mathrm{s}$ connected through fiber optic cable to an AN-FM-PCM30 switch is provided by the Internet Service Provider (ISP). The network is then transmitted through Cat 6 Ethernet cables to a LAN switch. The LAN switch is further connected by way of Cat 6 Ethernet cables a Linux box which serves as a firewall and doubles as a Proxy Server. The LAN backbone serves as a transmitter by receiving network signals from the main NOC and appropriately transmitting the signals to other base stations located at six different points. A Cisco Aironet 1300 wireless bridge/access point with 12 $\mathrm{dBi}$ omni-antenna serving as the WLAN base station is connected to the LAN switch to bridge all the other six (6) Cisco Aironet 1300 outdoor units. At these six locations, the Cisco Aironet 1300 bridges are connected directly to local servers with one of the ethernet ports of a Dynamic Host Control Protocol (DHCP) server with two (2) network cards performing IP Address distribution and Network Address Translation (NAT). 


\subsection{UMaT Library ICT Infrastructure}

Fig. 1 depicts that network signals in the library are received from the main campus NOC by way of fibre optic cable connection through one of the Cisco Aironet 1300 outdoor units. The fibre cable is terminated on an hp procurve 2626 switch with fibre ports. The network is connected to a server computer running a windows 2012 server operating system. The server computer has two network cards, one performing IP address distribution and the other Network Address Translation (NAT). The network is then terminated and distributed through three (3) hp switches to the numerous users across the 3 floors of the library through Ethernet cables. The network is further extended to mobile users through wireless access point connections. Presently, there are six (6) access points deployed in the library. The server machine also hosts the library management software (Alexandria) which support the day-to-day running of the library. There is a study area fitted with (20) dedicated client computers with internet access which supports both undergraduate and postgraduate research activities.

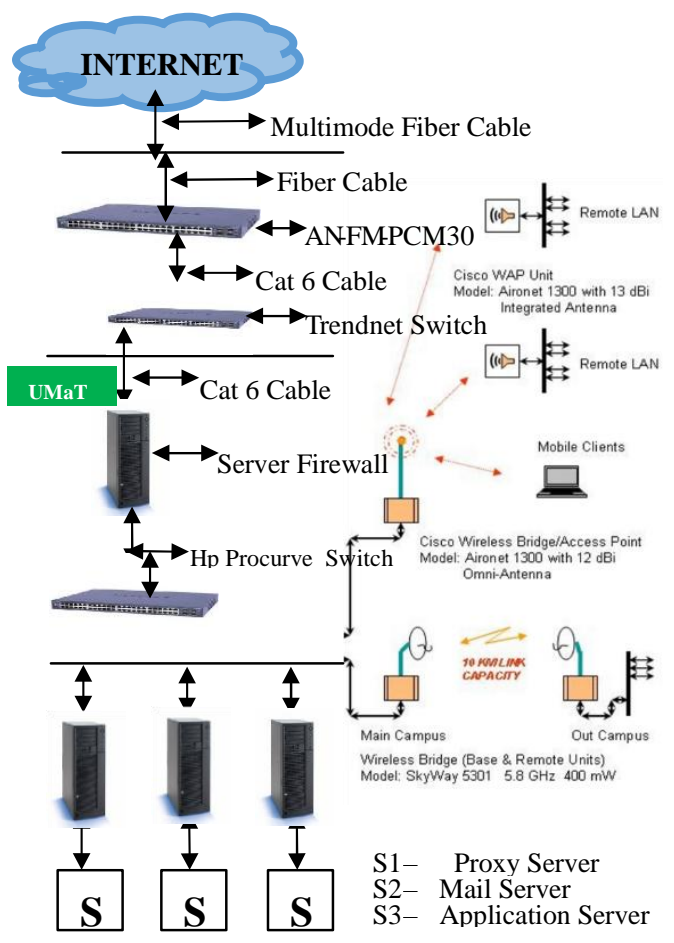

Fig. 1 UMaT Library ICT Infrastructure

\subsection{Library Organization, Services and Facilities}

UMaT library staff is made up of the Head Librarian, three Assistant librarians and 8 supporting staff. There are over 400 seats throughout the library, together with PC and laptop workstations, which offer students and other library users comfortable and varied environment in which to work either by themselves or with others. For individual study, a student can choose to work at a table. All study areas on the ground, first and second floors are designated for quiet individual study. There is one collaborative study room as well available for use located on the first floor. The room is intended for students working in groups on projects. UMaT library provides facilities and services on one-on-one basis and also through online. This online library services have opened a new horizon for the UMaT community. The Library page (http://www.umat.edu.gh/library) is designed to search library's collections, rules and regulations of using library services etc. Library users can also get access to online journals, through the Internet.

Table 1 Resource Materials in the UMaT library

\begin{tabular}{|l|l|}
\hline \multicolumn{1}{|c|}{ Types } & \multicolumn{1}{|c|}{ Quantity } \\
\hline Books & $\begin{array}{l}6600 \\
\text { Copies }\end{array}$ \\
\hline $\begin{array}{l}\text { Local journals/ } \\
\text { Periodicals/ Magazines }\end{array}$ & 50 Titles \\
\hline Report/Theses & 55 Titles \\
\hline $\begin{array}{l}\text { Undergraduate project } \\
\text { work }\end{array}$ & About 600 \\
\hline Online journals & $\begin{array}{l}+10,000 \\
\text { Titles }\end{array}$ \\
\hline National Newspapers & 6 Titles \\
\hline
\end{tabular}

Typically, types of collection in the UMaT Library are academic text books, periodicals / journals, light reading books, magazines, newsletters, related reference books, dissertations, pure reference books, reports, on-line journals and daily newspapers. Resources are arranged on the shelves by subject in alpha-numeric order and are classified according to the widely used Library of Congress Classification (LCC) Scheme. Library of Congress Subject Headings (LCSH) is used to determine subject matter of library materials. Books are catalogued according to Anglo-American Cataloguing Rules 2nd edition (AACR-2), and bibliographical data entered directly into the database using Library's integrated software system.

\section{Results and Discussion}

\subsection{Distribution of Hardware Equipment in UMaT Library}

Table 2 shows the number of hardware equipment in the library. $3 \mathrm{hp} 2626$ procurve switches and the patch panels have been terminated into the $30 \mathrm{U}$ rack in the main library NOC. The 2 remaining switches and patch panels have been terminated into $210 \mathrm{U}$ racks at the library café and process 
control room respectively. All the 25 client machines are CD-ROM tower computers that run windows 7 operating systems with at least $2 \mathrm{~GB}$ of internal memory. The server is a dell PowerEdge R720 rack mountable computer with four (4) network cards, 16 GB internal memory and 500 GB hard disk. The server runs Microsoft server 2012, acts as a DHCP server by distributing IP addresses to library users and holds the library management software (Alexandria). The wireless routers are mounted and connected by way of Cat 6 ethernet cables at vantage points in the library to disseminate internet wirelessly to mobile users. The barcode scanners are used by the library assistants to scan and keep records of borrowed books. The UPS are connected to serve as power backups for the computers. All the client machines in the café and the main library are connected to the internet by way Cat 6 ethernet cables. It is found that UMaT library has the basic hardware infrastructure to drive its processes with ICT.

Table 2 Distribution of Hardware Equipment in UMaT Library

\begin{tabular}{|l|c|}
\hline \multicolumn{1}{|c|}{ Hardware } & Quantity \\
\hline 30U Network Rack & 1 \\
\hline 10U Network Rack & 2 \\
\hline $\begin{array}{l}\text { Hp Procurve 2626 Switch in } \\
\text { library NOC }\end{array}$ & 4 \\
\hline $\begin{array}{l}\text { Hp Procurve 2626 Switch in } \\
\text { cafe }\end{array}$ & 1 \\
\hline Patch Panel work & 10 \\
\hline Server Computer & 15 \\
\hline $\begin{array}{l}\text { Client/Computer } \\
\text { stations in main library }\end{array}$ & 3 \\
\hline $\begin{array}{l}\text { Client/Computer work at café } \\
\text { attached to library }\end{array}$ & 1 \\
\hline Inkjet Printers & 6 \\
\hline Laser Photocopier & 5 \\
\hline UPS in the main library & 4 \\
\hline UPS in cafe & 3 \\
\hline Barcode Scanner & 1 \\
\hline Theft Detection Alarm & 15 \\
\hline $\begin{array}{l}\text { Wireless Routers in main } \\
\text { library }\end{array}$ & \\
\hline Cisco 1300 Wireless Router & 1 \\
\hline
\end{tabular}

\subsection{Distribution of Software in UMaT Library}

The different kinds of software used in the library are depicted in Table 3. Regarding server operating system, as seen from the table, the main library server runs on Microsoft Windows server 2012. All the 25 client machines both in the café and the main library runs on windows 7 operating system whilst the library management software running on the server is called Alexandria Companion. UMaT Space, an open source digital library management software also runs on the server. There is a bit of a variation in the usage of antivirus software. The 25 client machines use Kaspersky Internet Security whilst the server machine uses Kaspersky Total Security.

Table 3 Distribution of Software in UMaT Library

\begin{tabular}{|c|c|}
\hline Software & Quantity \\
\hline $\begin{array}{l}\text { Server Software (MS Server } \\
\text { 2012) }\end{array}$ & 1 \\
\hline Windows 7 & 25 \\
\hline $\begin{array}{l}\text { Library Management } \\
\text { Software }(\text { Koha })\end{array}$ & 1 \\
\hline $\begin{array}{l}\text { Kaspersky Internet Security } \\
\text { (Client Computers) }\end{array}$ & 25 \\
\hline $\begin{array}{l}\text { Kaspersky Total } \\
\text { (Server Computer) }\end{array}$ & 1 \\
\hline UMaTSpace & 1 \\
\hline $\begin{array}{lll}\text { Online } & \text { Public } & \text { Access } \\
\text { Catalogue (OPAC) } & \end{array}$ & 1 \\
\hline
\end{tabular}

\subsection{Status of Library Automation}

Automation of libraries has become the order of the day, due to the advancement in information technology and the need for information providers to move in this direction. Libraries cannot stay away from this revolution if they want to be relevant to their users, stakeholders and the public. It is not surprising that most libraries have embraced this evolution by changing from manual to automation.

To make this a possibility, a grant was received from the World Bank under the Teaching and Learning Innovation Fund (TALIF) for Government tertiary institutions in Ghana, which operates under the Education Sector Project of the Ministry of Education. The grant was to provide equipment to set up Internet services, procure and install library automation software for the institutions.

The automation process of the UMaT Library started in late 2007 but became live in 2010 . Automation was necessary because of the changing trends in the field of information technology. The whole of the UMaT Library staff was involved in the implementation of the automation project exercise while the installation and configuration of the hardware was jointly carried out by a contracted firm and the University Librarian who oversaw the implementation of the Library's automation project with the assistance of library staff. The Cataloguing Section of the Library has witnessed full conversion from manual to automated form. The Library subscribes to Online Computer Library Center (OCLC) database Cat 
Express for its copy cataloguing of library materials in a timely fashion.

\subsection{Status of Telecommunication Facilities}

Results from the survey conducted showed that the library has an intranet telephone system setup, CCTV installation but no telefax, audio visual and video conferencing facilities were also not in place.

\subsection{UMaT Library System}

The library software deployed in the Library is the Alexandria Companion. This Library system which is fully integrated includes the following modules: acquisition, cataloguing, circulation, orders, and Online Public Access Catalogue (OPAC). The Library's staff were given training in the use of different modules, including cataloguing and the OPAC. Other features such as Orders, Budgets, Vendors and Subscription are yet to be activated.

\subsection{Online Public Access Catalogue (OPAC)}

The OPAC system of the UMaT Library offers friendly and flexible search options to users through which they can search desired information from any bibliographical record in the library's database, such as author, title, subject, keyword, call number etc. Having an online catalogue offers tremendously increased means of accessing information contained in the catalogue. One can search by an author's name, by a title, by series, by a subject, or by any combination of these. This would have been impossible in a card catalogue environment. The system also has circulation information available and authenticated users can see what items they have checked out; they can place a recall/hold on items that are checked out to other users.

In addition to using OPAC, there is cataloguing utility, OCLC available, for a fee. Searching these databases, which are used by thousands of libraries to catalogue their collections, will let one know what libraries actually own copies of the items listed and this can enhance inter-lending services.

\subsection{Status of E-resources Availability and Accessibility}

Acquisition of electronic resources is a costeffective way for UMaT to add more holdings to the collection that is worth exploring. The Library provides the opportunity for users to access several full-text e-resources. Over 10,000 titled journals can be directly searched from the UMaT campus. The UMaT Library is a member of the Consortium of Academic and Research Libraries in Ghana
(CARLIGH) for getting access to full-text articles, abstracts, and bibliographical information of online journals of different publishers on different disciplines. Currently, the Library provides access to thirty-three (33) on-line journal databases through the consortium, and some freely available ones. However, because it is a consortium, choice is not down to individual libraries; it is therefore vitally important that UMaT library has a strong presence in this partnership. The library ensures that it I represented at every meeting twice a year, as well as maintaining contact in other ways, in order to lobby for UMaT's interest. Where a subscription only permits partial access to a database (for example, in some cases access to latest year's journals is prohibited) the library ensures this information is communicated to the university's community, and the library ensures that all information regarding database access is up to date. The library has fliers that contain list of databases; this forms part of its Current Awareness Service to the university community.

\subsection{Distribution of Users with Regards to E- Resource Accessibility}

During the survey period between February and April 2017, 855 questionnaires were administered. Out of this number, 537 participants responded, all indicating that they accessed and used the library's electronic resources. This number was made up of 351 undergraduate students representing $65.36 \%$ of the respondents, 73 postgraduate students representing $13.60 \%$ of the respondents, 87 teaching staff representing $16.20 \%$ of the respondents, 21 non-teaching staff representing $3.91 \%$ and 5 library staff representing $0.93 \%$. From the above, it could be observed that the various facets of the university community were represented in the study. This representation is illustrated in Fig. 2.

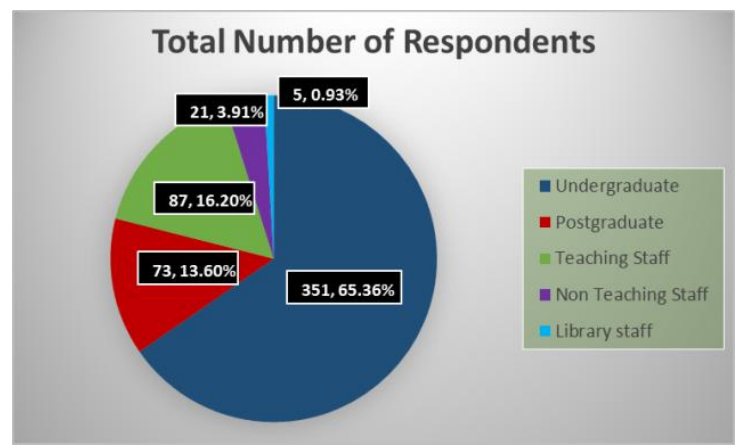

Fig. 2 Distribution of Users with regards to E-resource Accessibility and Usage 


\subsection{The Library Website}

The UMaT library website is the first point of contact for all users (undergraduate, postgraduate, teaching and non-teaching staff) of the library's online resources. The website provides pages with links to a host of paid and free access to e-journals databases. Some of the databases include Wiley On-line Library, EBSCO Host, Project Muse, American Institute of Physics, American Chemical Society, and many more. The free e-journal databases facilitate research activities of users as it helps them to search and browse research publications, peer reviewed articles, e-books etc. However, it has been noted that there is the need for the library to begin listing such resources under subject headings so that retrieval of information becomes easier.

\subsection{ICT Policy}

From the survey carried out, it became evident that the library has no well written ICT Policy to govern and guide how IT resources are acquired, accessed and used.

\subsection{Barriers to ICT Usage}

From the survey, it became evidently clear that in spite of the availability of ICT infrastructure for accessing and using electronic resources, some barriers hindered the full implementation and usage of electronic resources. The responses of the respondents to indicate their agreement to some problems associated with accessing and using electronic resources is summarised in Table 4.

It could be observed from Table 4 that majority of the respondents agreed to ICT related problems associated with accessing electronic resources, predominantly lack of ICT policy and unstable power supply with $95.72 \%$ and $94.41 \%$ of the respondents respectively.

\begin{tabular}{|c|c|c|c|c|c|c|}
\hline Barriers to ICT Usage & $\begin{array}{c}\text { Teaching } \\
\text { Staff } \\
(87)\end{array}$ & $\begin{array}{l}\text { Postgraduate } \\
\text { Students } \\
\text { (71) }\end{array}$ & $\begin{array}{l}\text { Undergraduate } \\
\text { Students (351) }\end{array}$ & $\begin{array}{c}\text { Non- } \\
\text { Teaching } \\
\text { Staff } \\
(21)\end{array}$ & $\begin{array}{l}\text { Library } \\
\text { Staff } \\
(5)\end{array}$ & Total (537) \\
\hline $\begin{array}{l}\text { Inadequate } \\
\text { facilities }\end{array}$ & 45 & 60 & 340 & 18 & 5 & $\begin{array}{c}468 \\
(81.15 \%)\end{array}$ \\
\hline $\begin{array}{l}\text { Inadequate } \\
\text { budget }\end{array}$ & 70 & 50 & 190 & 10 & 4 & $\begin{array}{c}324 \\
(60.33 \%)\end{array}$ \\
\hline $\begin{array}{l}\text { Unwillingness } \\
\text { to use ICT } \\
\text { tools }\end{array}$ & 60 & 65 & 295 & 14 & 5 & $\begin{array}{c}339 \\
(63.12 \%)\end{array}$ \\
\hline $\begin{array}{l}\text { Lack of } \\
\text { ICT policy }\end{array}$ & 80 & 69 & 340 & 20 & 5 & $\begin{array}{c}514 \\
(95.72 \%) \\
\end{array}$ \\
\hline $\begin{array}{l}\text { Unstable } \\
\text { power } \\
\text { supply } \\
\end{array}$ & 80 & 62 & 340 & 20 & 5 & $\begin{array}{c}507 \\
(94.41 \%)\end{array}$ \\
\hline $\begin{array}{l}\text { Lack of ICT usage skills } \\
\text { of users }\end{array}$ & 79 & 60 & 301 & 15 & 4 & $\begin{array}{c}459 \\
(85.47 \%)\end{array}$ \\
\hline $\begin{array}{l}\text { Inadequate } \\
\text { ICT skill } \\
\text { of Library } \\
\text { staff }\end{array}$ & 70 & 65 & 310 & 12 & 3 & $\begin{array}{c}460 \\
(85.66 \%)\end{array}$ \\
\hline $\begin{array}{l}\text { Inadequate } \\
\text { Training } \\
\text { for Library } \\
\text { Staff }\end{array}$ & 60 & 61 & 290 & 15 & 5 & $\begin{array}{c}431 \\
(80.26 \%)\end{array}$ \\
\hline $\begin{array}{l}\text { Lack of commitment by } \\
\text { Management }\end{array}$ & 50 & 62 & 315 & 10 & 4 & $\begin{array}{c}441 \\
(82.12 \%)\end{array}$ \\
\hline
\end{tabular}




\subsubsection{The way forward}

UMaT Library has embarked upon the following courses of action to help to put more vibrancy into the accessibility of electronic resources:

\section{(i). Provision of Digital institutional repository services}

UMaT Library has embraced the open access concept and has installed Dspace software for its institutional repository. An Assistant Librarian has been mandated to oversee this new project. Most of the postgraduate thesis, conference papers, and research articles by staff have been scanned and uploaded on to the Dspace. The University's Dspace is called UMaTSpace. Customisation of the UMaTSpace is still ongoing and has not been activated live to the University community due to some technical challenges. However, the library has started marketing it to its community through distribution of brochures and flyers which highlight its benefits for lecturers, researchers and the institution as a whole.

\section{(ii). Implementation of Information Literacy Programme}

The Library believes in the importance of lifelong learning that would equip students, staff and other users to become information literates who would be able to know when, where and how to access information. The library is currently drafting an Information Literacy Course syllabus for approval by the Academic Board of the university, so that the programme could take off next academic year. Information literacy for students needs to be a compulsory course built into the curriculum and assessed; it should go hand in hand with other critical thinking skills the university is developing such as Communication Programme being developed by the University. Ideally, students should start undertaking this programme during the 1 st semester of the first year. It is projected that the Library would continue to provide Information Literacy lessons that students could use to build up or refresh their information retrieval skills. In doing so, it is estimated that by the time they come to searching literature for project reports or theses, students should have an excellent knowledge of what sources are available to them, and the skills needed to search them effectively.

\section{Conclusions}

This paper sought to examine ICT infrastructure and its impacts on library and information services at UMaT. It is clear from the study that the UMaT library has implemented a robust ICT infrastructure that is suitable for accessing online resources for teaching, learning and research purposes in terms of hardware and software. The research revealed that the staff strength of the University Library is inadequate to perform excellent tutorials to prospective users on how to access the universitysubscribed and free online resources. Again, the study concludes that the library has some basic hardware facilities like servers, computers, printers, scanner, barcode readers, CD-ROM Tower, CDWriter, etc. Presently, the library has only three (3) access points deployed on each floor; this is considered woefully inadequate considering the number of people who visit the library daily. In most cases effective utilisation of the excellent ICT infrastructure to improve access to online resources is hindered by numerous problems leading to their underutilization. Moreover, the UMaT library need a well-written ICT policy to clearly define access and usage patterns of ICT equipment. The library staff who play a vital role in accessing online resources in the library must be given adequate training in ICT so as to make optimum use of the resources at their disposal. Trained professionals with ICT having positive attitude will ensure the development of libraries. To achieve this, the university must continue to invest in technology to improve the library's collections and services.

\section{References}

Anon. (2018), "Investiture of Chancellor", Recorder, University of Mines and Technology, Tarkwa, Vol. 1, pp. 6 - 7.

Dafiaghor, F. K. (2012), "Problems and prospects of electronic resources usage in Nigerian academic libraries", Journal of Economics and International Finance, Vol. 4, No.9, pp. 220225.

Daniel, J. O. (2000), "Virtual Library for Nigerian Libraries", Nigerian Libraries, Vol. 36, No.2, $56 \mathrm{pp}$.

Ddembe, W. \& Baryamureeba, V. (2006). An investigation of heads of computing departments in higher education, In V. Baryamureeba \& W. Ddembe (Eds.), Measuring computing research excellence and vitality, Kampala: Fountain Publishers, pp. 3-12

Idowu, A. O. (2009), "E-Resources and Internet Accessibility: Challenges of Library Service In Nigeria", 3rd Jire Olanlokun Annual Memorial Lecture, pp. 1-6.

Anon. (2010), National Institution for Academic degrees and University Evaluation, Tokyo, 1- 
29-1, Gakuen-Nishimachi, www.niad.ac.jp. Accessed: March 20, 2017.

Johnston, S. and McCormack, C. (1996), "Integrating information technology into University teaching identifying the needs and providing support", International Journal of Education Management, Vol.10, No.5, pp. 36 42.

Nok, G. (2006), "The challenges of computerizing a university library in Nigeria: the Kashim Ibrahim library, Ahamadu Bello University, Zaria", Library Philosophy and Practice, Vol.8, No.2, pp. 4 - 6.

Nwalo, K. I. N. (2002), Fundamentals of library routines. Stirling Horden Publishers, Ibadan, $512 \mathrm{pp}$.

O'Brien, J. A. (2002), Management Information systems, 5th ed., $314 \mathrm{pp}$.

Ogunsola, L.A. (2004), "Nigerian University Libraries and the challenges of Globalization: The Way Forward", Electronic Journal of Academic and Special Librarianship, Vol.5, p. 23.

Omagbemi, C. O., Akintola, B.A., and Olayiwola, I.B. (2004). Academic Libraries, the Internet and its Potential Impact on Teaching and Learning in Nigerian Tertiary Institutions. Journal of Library and Information Science, Vol. 1\&2, pp. 38-39.

Ray, K and Day, J (1998), "student attitudes towards electronic information resources", Retrieved from <http://information.net/ir/42/paper 54html. Accessed: March 20, 2010.

University Grants Commission, Bangladesh (2001), Annual Report, 2001.Dhaka, UGC, Bangladesh, pp. 65 - 105.

Utor, J. K. (1999), "The role of information services in school libraries in a democratic culture": a compendium of papers presentations of the 1999 NLA annual national conference and $A G M$, May $8^{\text {th }}-14^{\text {th }} 1999,13 \mathrm{pp}$.

\section{Authors}

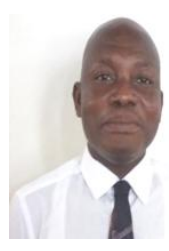

P. Anafo is a Senior Assistant Librarian at the University of Mines and Technology. He holds an MA degree in Library Studies from the University of Ghana. He is a member of the Ghana Library Association. His research areas are Information Literacy, Institutional Repository and Electronic Resources.

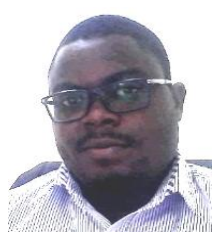

S. Akpah is a lecturer with the Computer Science and Engineering Department at the University of Mines and Technology. He obtained his MSc (Hons) and BSc (Hons) degrees in Information and Technology from the Kwame University of Science and Technology, Kumasi and Ghana Telecom University College, Accra respectively. His research interest lies in the areas of Local Area Network Infrastructure Design and Management, Wireless Securities, Bandwidth Optimisation Techniques and Healthcare Cloud Systems.

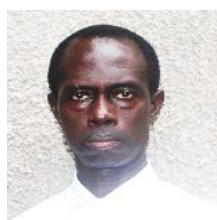

Y. Ofori is an Assistant Librarian at the University of Mines and Technology, Tarkwa with a wide range of experience in the library profession. He obtained MA in Library Studies, BA in Information Studies and Diploma in Librarianship, all from the University of Ghana. His research interest includes Collection Development, Information Literacy and Indexing 